\title{
Physicochemical, microbiological and sensory properties of red beet vinegar
}

\author{
Kırmızı pancar sirkesinin fizikokimyasal, mikrobiyolojik ve duyusal \\ özellikleri
}

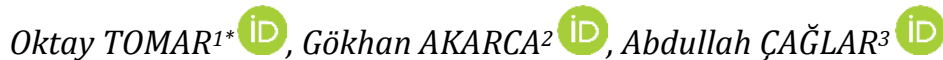 \\ 1,3Department of Agricultural Economics, Faculty of Agriculture and Natural Science, Kocaeli University, Kocaeli, Turkey. \\ oktaytomar@hotmail.com, acaglar@aku.edu.tr \\ ${ }^{2}$ Department of Food Engineering, Engineering Faculty, Afyon Kocatepe University, Afyonkarahisar, Turkey. \\ gakarca@aku.edu.tr
}

\begin{abstract}
This study determined that physicochemical, microbiological and sensory properties of red beet vinegar. The color values of red beet vinegar were $L^{*}: 2.55, a^{*}: 1.54$ and $b^{*}:-0.98$. The mean $p H$, dry matter\%, ${ }^{\circ} \mathrm{Brix}$, ash\%, density and conductivity values of vinegar samples were $2.94 \pm 0.32,3.30 \pm 0.12,3.71 \pm 0.17,0.24 \pm 0.21,1.003 \pm 0.002 \mathrm{~g} / \mathrm{cm}^{3}$ and $2.13 \pm 0.042 \mu \mathrm{S} / \mathrm{cm}$, respectively. The mean antioxidant value of vinegar samples produced from the red beet was $96.14 \pm 3.43 \mu \mathrm{g} \mathrm{TE} / \mathrm{mL}$ and the total phenolic content was $1170.78 \pm 20.95 \mathrm{mg}$ GAE/L. Of the mineral contents, Na was determined to be the highest with $370.94 \pm 2.73 \mathrm{ppm}$, followed by $K$ with $69.13 \pm 1.13 \mathrm{ppm}$, $P$ with $14.5 \pm 0.01 \mathrm{ppm}$ and Ca with $10.07 \pm 0.42 \mathrm{ppm}$. Following the fermentation process, the mean acetic bacterial count in vinegar samples was $3.06 \pm 0.14 \log \mathrm{cfu} / \mathrm{mL}$ while the mean lactic acid bacterial count was $2.84 \pm 0.09 \mathrm{log} \mathrm{cfu} / \mathrm{mL}$ and the mean yeast/mold count was $1.09 \pm 0.08 \mathrm{log} \mathrm{cfu} / \mathrm{mL}$. According to the sensory analysis results, the highest score was determined to be $7.67 \pm 0.57$ in color score whereas the lowest score was $5.05 \pm 0.21$ in aroma score. The general appreciation score of the red beet vinegar was $6.75 \pm 0.35$.
\end{abstract}

Keywords: Red beet, Vinegar, Antioxidant, Phenolic compound.
Öz

Bu çalıșmada; kırmızı pancar sirkesinin fizikokimyasal, mikrobiyolojik ve duyusal özellikleri belirlenmistir. Kırmızı pancar sirkesinin renk değerleri, $L^{*}: 2.55, a^{*}: 1.54$ ve $b^{*}:-0.98$ olarak tespit edilmiştir. Sirke örneğinin ortalama $\mathrm{pH}$, \% Kuru Madde, ${ }^{\circ}$ Brix, \% kül miktarları, yoğunluk ve iletkenlik değerleri sirasiyla; $2.94 \pm 0.32,3.30 \pm 0.12$, $3.71 \pm 0.17,0.24 \pm 0.21,1.003 \pm 0.002 \mathrm{~g} / \mathrm{cm}^{3}$ ve $2.13 \pm 0.042(\mu \mathrm{S} / \mathrm{cm})$ olarak saptanmıştır. Kırmızı pancardan üretilen sirke örneğinin ortalama antioksidan değerleri $96.14 \pm 3.43 \mu \mathrm{g} T E / \mathrm{mL}$ ve toplam fenolik madde miktarları ise $1170.78 \pm 20.95 \mathrm{mg}$ GAE/L olarak saptanmıstır. Tespit edilen mineral maddeler arasindan en fazla $370.94 \pm 2.73 \mathrm{ppm}$ ile $\mathrm{Na}$ olduğu, bunu $69.13 \pm 1.13$ ppm ile K, $14.5 \pm 0.01$ ppm ile P ve $10.07 \pm 0.42$ ile de Ca'un izlediği görülmüşürr. Fermantasyon sonrasinda sirke örneğinde ortalama asetik bakteri sayısl; $3.06 \pm 0.14$, laktik asit bakteri saylsl; $2.84 \pm 0.09$ ve maya/küf saylsl; $1.09 \pm 0.08 \mathrm{log} \mathrm{kob} / \mathrm{mL}$ olarak belirlenmistir. Panelistler tarafindan yapılan duyusal analiz sonuçlarına göre; en yüksek puanı $7.67 \pm 0.57$ ile sirkenin rengi alırken en düșük puanı ise, 5.05 0.21'lik değer ile sirkenin aroması almıștır. Kırmızı pancar sirkesinin genel beğeni puanı ise $6.75 \pm 0.35$ olarak tespit edilmiștir.

Anahtar kelimeler: Kırmızı pancar, Sirke, Antioksidan, Fenolik madde.

\section{Introduction}

Vinegar is a natural product, produced by fermenting different agricultural raw materials, containing edible carbohydrate sources to ethyl alcohol by yeasts and then the fermentation of the ethyl alcohol to acetic acid by acetic acid bacteria such as Acetobacter, Gluconobacter, and Gluconacetobacter [1]-[4].

Vinegar is used not only as a seasoning ingredient but also as a medicine [5],[6]. Depending on the type and composition of the raw material it is produced, vinegar can contain bioactive components in different types, amounts, and proportions. Its effects on health are related to these bioactive components [7]. Today, different kinds of vinegar are produced in the World from different kinds of raw materials including grapes, apples, sugar cane, rice, barley, various fruits and vegetables [8].

Red beet (Beta vulgaris var. cruenta) is a flowering root vegetable, belonging to the Amaranthaceae family. It is cultivated in regions with mild climates such as the Mediterranean region, Western and Eastern Europe [9]. Color substances, mostly composed of betanin [10] are very rich in terms of betalains [11],[12]. Red beet is widely used as a natural coloring agent in many dairy and meat products (milk, ice cream, yogurt, kefir, sausage, and salami), beverages (fruit juices, carbonated drinks) and confectionery products [13],[14].

Red beet contains high amounts of minerals including $\mathrm{K}, \mathrm{Mg}$, Ca. It is also rich in Fe and is a good source of Vitamins B9 (Folate) and C. Red beet contains high levels of citric and malic acid, as well as shikimic acid [15]. Also, it has been reported that it has a very rich folic acid and amino acid content [14].

Betalains have many beneficial biological activities including antioxidant, anti-inflammatory, hepatoprotective and antitumor properties, in addition to red coloration [16],[17]. Red beet antioxidant values are substantially higher compared to those in many similar vegetables [18].

${ }^{*}$ Corresponding author/Yazışılan Yazar 
In this study, it is aimed to determine the physicochemical, microbiological and sensory properties of vinegars made of red beets, which are rich in minerals such as sodium, potassium, phosphorus, and vitamins such as A, B, C, proteins and high antioxidant capacity, as opposed to grape and apple vinegar.

\section{Materials and method}

\section{$2.1 \quad$ Materials}

The red beets used in the research were obtained from the local markets in Afyonkarahisar. Then, $1000 \mathrm{~g}$ samples of red beet were taken and sliced using a knife in 10-cm-sided cubes and placed into glass jars (Şişe Cam, Turkey) ( $5 \mathrm{~L}$ ) at $1 / 3$ ratio. For the natural fermentation process, $50 \mathrm{~g}$ honey (Özkovan, Turkey) and 1\% yeast Saccharomyces cerevisiae culture (Dry yeast, Pakmaya, Turkey) were added to the jar. Also, $150 \mathrm{~mL}$ additive-free red beet vinegar previously produced with a similar method was added to the jar to form the fermentation conditions. Then, water was added to the jar until the total volume reached $5 \mathrm{~L}$. The brim of the jar was closed using a cloth that will allow air intake and the samples were kept in a dark place in the laboratory at $20 \pm 2{ }^{\circ} \mathrm{C}$ for three months.

At the end of this period, the main vinegar culture gel formed on the surface, sediment and the vinegar was separated from each other by filtration using a coarse filter paper. The filtered vinegar was placed in $500 \mathrm{ml}$ colored-glass bottles and their lids were closed. The bottles were then refrigerated at $4{ }^{\circ} \mathrm{C}$.

\subsection{Method}

\subsubsection{Physicochemical analyses}

The color values of red beet vinegar samples were measured using a Konika Minolta Chromameter (CR-400, Japan) using the CIE LAB system [19]. pH measurements of vinegar samples were carried out using a Hanna HI 2215 pH meter (Germany) [20]. The titrimetric method was adopted to determine the total acidity and the results were given in acetic acid g/L [21]. The ${ }^{\circ}$ Brix values of the vinegar samples were determined in Brix\% by digital refractometer (Atago PAL1, Japan) at room temperature [22]. Dry matter, ash and alcohol content analyses were carried out according to AOAC 930.15, 923.03, 52.03 rescpectively [20]. Density was measured using a pycnometer as described by [23]. Conductivity values were measured in $\mathrm{mS} / \mathrm{cm}$ using a manual conductivity measuring device (Sension 5 model Hach, CO, USA) [24].

\subsubsection{Total phenolic content}

Total phenolic content was determined by the Folin-Ciocalteu method and the absorbance values were determined using a spectrophotometer (Shimadzu UV-1208, Japan). Results were determined in mg GAE/L [25].

\subsubsection{Determination of antioxidant activity}

For the determination of antioxidant activity, the method used by Molyneux [26] was adopted. Samples diluted with methanol were treated with the DPPH solution, then it was left to stand for thirty minutes at room temperature in the dark. The absorbance values of the samples and the control sample were then read on a spectrophotometer at $517 \mathrm{~nm}$ (Shimadzu UV1208, Japan). The results were expressed in Trolox-equivalent antioxidant capacity (TEAC).

\subsubsection{Determination of mineral content}

ICP-OES (Plasma Quant PQ 9000, Germany) was used for the determination of mineral substances. The samples were burned using acid and heat before their analysis using ICP. Then, $5 \mathrm{~mL}$ of vinegar, $5 \mathrm{~mL}$ of nitric acid and $2.5 \mathrm{~mL}$ of hydrogen peroxide were used to break down the samples taken into Teflon microwave tubes with acid. The combustion was carried out in a microwave combustion unit (Cem Mars 6, USA) [27].

\subsubsection{Microbiological analysis}

To determine the acetic acid bacterial counts of the vinegar samples, Yeast Extract Calcium Carbonate Glucose Agar (Himedia, M1182, India) was used. The Petri dishes were incubated in an incubator (Incucell, MMM, Germany) for 5-10 days at $30{ }^{\circ} \mathrm{C}$ under aerobic conditions [28]. Lactic acid bacterial counts were determined using de Man Rogosa and Sharpe Agar (MRS) (Merck, 1.10660, Germany) media. The Petri dishes were then taken into the jars (Merck 1.16387), an Anaerocult C (Merck, 116375, Germany) prepared appropriately was added and the jar was incubated in an incubator (Incucell, MMM, Germany) under anaerobic conditions at $30{ }^{\circ} \mathrm{C}$ for 24-48 hours [29]. Rose Bengal Chloramphenicol Agar (Merck 1.00467) (RBC) was used to determine the yeast/mold counts and the Petri dishes were incubated for 5-7 days at $22^{\circ} \mathrm{C}$ under aerobic conditions [30]. Inoculations were carried out according to the spread plate method.

\subsubsection{Sensory analyses}

For the sensory analyses of vinegar samples, a panelist group consisting of 20 faculty members of Afyon Kocatepe University Faculty of Engineering Food Engineering Department and graduate and post-graduate students participated in the sensory evaluations. The 9-point hedonic scale was used in the analyses. The scale was established as; $<4$ unacceptable, 4-5 bad, 5-6 medium, 6-7 good, 7-8 very good, $>8$ perfect [31],[32].

\subsubsection{Statistical analysis}

This study was conducted in triplicate, and two parallels were used for each repetition.

\section{Results and discussion}

The mean color values of red beet vinegar samples are given in Table 1 . The mean $\mathrm{L}^{*}$ value of the samples was 2.55 , the mean $a^{*}$ value of the samples was 1.54 and the mean $b^{*}$ value of the sampleswas -0.98. Er [33], for the color values of red beet samples subjected to different pre-treatment and drying temperatures, have reported the $\mathrm{L}^{*}$ value between 25.86 and 32.26 , the $\mathrm{a}^{*}$ value between 8.96 and 22.64 and the $\mathrm{b}^{*}$ value between 1.91 and 14.27. The values indicated by the researcher were in line with the results of the present study, except for the $a^{*}$ value. The differences in the $a^{*}$ value were related to the differences in the production processes.

Table 1. Color ( $\mathrm{L}^{*}, \mathrm{a}^{*}$ and $\left.\mathrm{b}^{*}\right)$ values of red beet vinegar.

\begin{tabular}{cc}
\hline Analysis & Value \\
\hline $\mathrm{L}^{*}$ Value & $26.55 \pm 0.46$ \\
$\mathrm{a}^{*}$ Value & $1.54 \pm 0.03$ \\
$\mathrm{~b}^{*}$ Value & $-0.98 \pm 0.29$ \\
\hline
\end{tabular}

Following a three-month-fermentation period, the mean $\mathrm{pH}$ value of red beet vinegar samples was found to be $2.94 \pm 0.32$ (Table 2). Similarly, Unal [21], in vinegar samples obtained 
from Dimrit grapes by different methods, found the $\mathrm{pH}$ value in the range of 2.68-2.85. Also, Budak et al. [34], in apple cider vinegar samples produced by different methods have reported the $\mathrm{pH}$ values in the range of 2.83-3.21. Chemical analysis results of red beet vinegar samples are shown in Table 2.

Table 2. Chemical analysis results of red beet vinegar.

\begin{tabular}{cc}
\hline Analysis & Value \\
\hline $\mathrm{pH}$ & $2.94 \pm 0.32$ \\
Total acidity (g/L) & $27.87 \pm 0.38$ \\
Brix ( ${ }^{\circ}$ Brix) & $3.71 \pm 0.17$ \\
Total dry matter (\%) & $3.30 \pm 0.12$ \\
Ash (\%) & $0.24 \pm 0.21$ \\
\hline
\end{tabular}

The mean total dry matter value of the vinegar samples was $3.30 \pm 0.12 \%$ while the mean Brix ( ${ }^{\circ} \mathrm{Brix}$ ) value was $3.71 \pm 0.17$ (Table 2). According to the TS 1880 EN 13188 vinegar standard, there is no limit specified regarding the dry matter content of the vinegar [35]. Aykın [36] has reported that the mean dry matter content of apple cider vinegar samples between $2.14 \%$ and $2.42 \%$. Kadaş [37] has reported that the mean ${ }^{\circ}$ Brix values in hawthorn vinegar samples as $5.33^{\circ}$ Brix. In their study, Marangoz [38] found the ${ }^{\circ}$ Brix values in black mulberry vinegar after alcohol fermentation and acidification as 2.65 and 1.8 ${ }^{\circ}$ Brix, respectively. Examining the studies, it was seen that the findings of the present research were similar to those reported by Marangoz[38] but lower than those obtained by Kadas[37]. The mean ash content of red beet vinegar was determined to be $0.24 \pm 0.21 \%$ (Table 2). According to the TS 1880 EN 13188 vinegar standard, ash value should be $0.05 \mathrm{~g} / \mathrm{L}$ minimum [35]. Accordingly, it was found that the red beet vinegar samples complied with the values specified in the standard in terms of ash content. In similar studies, Budak [32], has reported that the total dry matter content of apple and grape vinegar samples varied between $1.94 \%$ and $4.98 \%$. Aykın [36], has stated that the ash content of apple and pomegranate vinegar samples was $0.22 \%$ and $0.39 \%$, respectively, similar to those obtained in our research results.

The mean density value of vinegar samples was found to be $1.003 \pm 0.002 \mathrm{~g} / \mathrm{cm}^{3}$ (Table 3 ). In similar studies, the density values of vinegar samples have been reported as 0.9987-1.0517 $\mathrm{g} / \mathrm{cm}^{3}$ by Budak [32] and 1.013-1.024 $\mathrm{g} / \mathrm{cm}^{3}$ by Plessi[39]. The findings obtained in the studies were in line with the results obtained in the present study. The mean conductivity value of the vinegar sample in the present study was found to be $2.13 \pm 0.042(\mu \mathrm{S} / \mathrm{cm})$ (Table 3). Siddeeg et al. [40] have reported the mean conductivity value as $3.10 \pm 0.15 \mathrm{mS} / \mathrm{cm}$, while Kadas et al. [41] have reported the mean conductivity value as $3.86 \pm 0.45 \mathrm{mS} / \mathrm{cm}$. As a result of a three-month-fermentation period, alcohol was not detected in the red beet vinegar samples.

Table 3. Density, conductivity, alcohol, total antioxidants and total phenolic content amounts of red beet vinegar.

\begin{tabular}{cc}
\hline Analysis & Value \\
\hline Density $\left(\mathrm{g} / \mathrm{cm}^{3}\right)$ & $1.003 \pm 0.002$ \\
Conductivity $(\mu \mathrm{S} / \mathrm{cm})$ & $2.13 \pm 0.042$ \\
Alcohol $(\%)$ & - \\
Total antioxidants $(\mu \mathrm{g} \mathrm{TE} / \mathrm{mL})$ & $96.14 \pm 3.43$ \\
Total phenolic content $(\mathrm{mg} \mathrm{GAE} / \mathrm{L})$ & $1170.78 \pm 20.95$ \\
\hline
\end{tabular}

The mean antioxidant value of red beet vinegar was $96.14 \pm 3.43$ $\mu \mathrm{g} \mathrm{TE} / \mathrm{mL}$ while the mean total phenolic content was $1170.78 \pm 20.95 \mathrm{mg} \mathrm{GAE} / \mathrm{L}$ (Table 3). Unal [21] has reported the total phenolic compound value of the vinegar samples in terms of gallic acid in the range of 423.90-499.90 mg/L. Ozturk et al. [42] have reported that the total phenolic content of the red beet was $944 \pm 22 \mathrm{GAE} \mathrm{mg} / \mathrm{g}$.

$\operatorname{Er}$ [33] has reported that the antioxidant capacity (DPPH) value of the red beet that was subjected to different pre-treatment and drying temperatures in methanol extract varied between $1771 \mu$ mol Trolox equivalent/100 g and $5133 \mu$ mol Trolox equivalent/100 $\mathrm{g}$ and the phenolic compound value in methanol extract between $671.1 \mathrm{mg} \mathrm{GAE} / 100 \mathrm{~g}$ and $1399.8 \mathrm{mg}$ GAE/100 g. Kayın [9] has determined the antioxidant value of red beet concentrate to be $151.4 \mu \mathrm{M}$ Trolox/100 mL. Antioxidant values obtained in our study were substantially higher than the studies mentioned above. Therefore, the functional properties of red beet, which is rich in phenolic and antioxidant compounds, were found to increase with vinegar production.

The mineral substances detected in red beet vinegar and their mean values are shown in Table 4 . It was determined that the most abundant mineral was $\mathrm{Na}$ with $370.94 \pm 2.73 \mathrm{ppm}$, followed by K with $69.13 \pm 1.13 \mathrm{ppm}$, P with $14.5 \pm 0.01 \mathrm{ppm}$ and Ca with $10.07 \pm 0.42 \mathrm{ppm}$. It was also determined Sn $7.34 \pm 0.11$ ppm, Mg $3.25 \pm 0.07$ ppm, Fe $0.22 \pm 0.01$ ppm, B $0.17 \pm 0.00$ ppm, Al $0.09 \pm 0.00 \mathrm{ppm}$ and $\mathrm{Mn} 0.03 \pm 0.00 \mathrm{ppm}$. In similar studies conducted on the subject, Ozturk et al. [42] have reported the $\mathrm{Na}$ and $\mathrm{Ca}$ values in the range of $27.70-4070.20 \mathrm{mg} / \mathrm{L}$ and $627.10-1599.70 \mathrm{mg} / \mathrm{L}$, respectively, while Kapukaya [43] has reported the $\mathrm{Mg}$ and $\mathrm{Fe}$ values as $0.64 \mathrm{ppm}$ and $1.37 \mathrm{ppm}$, respectively, and Aykın [36] has reported the $K$ value as $25814.17 \mathrm{mg} / \mathrm{L}$. Kadas et al [41], in their research on hawthorn vinegar, determined the mineral values as $6638.7 \pm 452.7 \mathrm{ppm}$ for $\mathrm{K}, 521.4 \pm 39.5$ for $\mathrm{Ca}, 241.9 \pm 43.7 \mathrm{ppm}$ for $\mathrm{Mg}, 240.0 \pm 28.3$ ppm for Fe, 123.1 $\pm 21.3 \mathrm{ppm}$ for $\mathrm{Na}, 40.1 \pm 9.8 \mathrm{ppm}$ for $\mathrm{Zn}$ and $0.273 \pm 0.5 \mathrm{ppm}$ for $\mathrm{Cu}$.

Table 4. Amounts of mineral substances detected in red beet vinegar (ppm).

\begin{tabular}{lcc}
\hline & Minerals & Value \\
\hline & $\mathrm{Na}$ & $370.94 \pm 2.73$ \\
$\mathrm{Mg}$ & $3.25 \pm 0.07$ \\
$\mathrm{~K}$ & $69.13 \pm 1.13$ \\
$\mathrm{Ca}$ & $10.07 \pm 0.42$ \\
$\mathrm{P}$ & $14.5 \pm 0.01$ \\
$\mathrm{Fe}$ & $0.22 \pm 0.01$ \\
$\mathrm{~B}$ & $0.17 \pm 0.00$ \\
$\mathrm{Mn}$ & $0.03 \pm 0.00$ \\
& $\mathrm{Al}$ & $0.09 \pm 0.00$ \\
& $\mathrm{Sn}^{*}$ & $7.34 \pm 0.11$ \\
\hline *: ppb. & &
\end{tabular}

After the fermentation, the mean acetic bacterial count of vinegar sample was $3.06 \pm 0.14$ while the lactic acid bacteria count was $2.84 \pm 0.09$ and yeast/mold count was $1.09 \pm 0.08$ log $\mathrm{cfu} / \mathrm{mL}$ (Table 5). Sengun and Kilic [44], in homemade mulberry vinegar samples, have reported the acetic acid bacteria, lactic acid bacteria and yeast/mold count as 2.84, 3.17 and $1.32 \log \mathrm{cfu} / \mathrm{mL}$, respectively. In the same study, the researchers determined these values as $1.65,1.03$ and $1.47 \mathrm{log}$ $\mathrm{cfu} / \mathrm{mL}$ in commercial mulberry vinegar samples. The microbiological results obtained in the study were similar to those of homemade vinegar samples but higher than those of commercial vinegar samples, except for yeast/mold counts. It was thought that the differences obtained in the study were related to the raw materials and processes adopted in production. 
Table 5. Microbiological analysis results for vinegar sample.

\begin{tabular}{cc}
\hline Microorganism count (Log CFU/mL) & Value \\
\hline Acetic acid bacteria & $3.06 \pm 0.14$ \\
Lactic acid bacteria & $2.84 \pm 0.09$ \\
Yeast / Mold & $1.09 \pm 0.08$ \\
\hline
\end{tabular}

According to the sensory analysis results of the panelists (Table 6), the highest score was determined to be $7.67 \pm 0.57$ in color scores whereas the lowest score was $5.05 \pm 0.21$ in aroma scores. The mean general evaluation score of the red beet vinegar was $6.75 \pm 0.35$. According to the results of the analysis, the vinegar obtained from red beet was found to have acceptable properties.

Table 6. Sensory evaluation scores of vinegar sample.

\begin{tabular}{cc}
\hline Sensory evaluation & Score \\
\hline Color & $7.67 \pm 0.57$ \\
Aroma & $5.05 \pm 0.21$ \\
Odor & $5.53 \pm 0.71$ \\
Consistency & $7.52 \pm 0.70$ \\
General appreciation & $6.75 \pm 0.35$ \\
\hline >8 perfect 7-8: Very good 6-7: Good 5-6: Medium 4-5:
\end{tabular}

$>8$ perfect 7-8: Very good, 6-7: Good, 5-6: Medium, 4-5: Bat, <4: Unacceptable.

\section{Conclusion}

Vinegar is a fermented product that is becoming more popular due to its positive effects on health and its usage in the food industry is increasing. In general, apple and grapes are preferred as raw materials in the food sector, but vinegar can be produced from all raw materials such as fruits, vegetables and even cereals containing sugar. In the present study, physicochemical, microbiological and sensory properties of red beet vinegar were investigated. The results showed that antioxidant capacity and total phenolic content of red beet vinegar were very high. Also, red beet vinegar was found to be rich in minerals such as $\mathrm{Na}, \mathrm{K}, \mathrm{P}, \mathrm{Ca}$ and $\mathrm{Mg}$. The consumption of red beet, which is known to be rich in bioactive components, is very low. The benefits of this product, which is consumed only locally, are unknown to many.

As a result of this research, it is thought that the marketing range of red beet vinegar should be enlarged from local to nation-wide in Turkey and red beet vinegar should be used not only as a seasoning in salads and sauces but as an alternative functional product in various areas. Thus, both the recognition and economic value of red beet will increase and an alternative product will be created to apple and grape vinegar commonly used in Turkey.

\section{Referance}

[1] Aktan N, Kalkan H. Vinegar Technology. 2nd ed. Izmir, Turkey, Ege University Printery, 1998.

[2] Budak NH, Aykin E, Seydim AC, Greene AK, Guzel-Seydim ZB. "Functional properties of vinegar". Journal of Food Science, 79(5), 757-764, 2014.

[3] Karabiyikli S, Sengun IY. Beneficial Effects of Acetic Acid Bacteria and Their Food Products. Editor: Sengun IY, Acetic Acid Bacteria: Fundamentals and Food Applications, 221-242, Boca Raton, Florida, USA, CRC Press, 2017.

[4] Bayram M, Kaya C, Yücel EE, Er B, Gülmez E, Terzioglu E. "Some quality properties of rice vinegar and various commercial vinegar samples". Academic Food Journal, 16(3), 293-300, 2018.

[5] Kırıcı H. Functional Vinegar Production from Güvem (Prunus spinosa) Fruit. MSc Thesis, Namik Kemal University, Tekirdag, Turkey, 2017.
[6] Gökırmaklı C, Budak HN, Güzel-Seydim ZB. "Effects of vinegar on health". The Journal of Food, 44(6), 1042-1058, 2019.

[7] Tan SC. Vinegar Fermentation. MSc Thesis, Louisiana State University, Lafayette, ABD, 2003.

[8] Garcia I, Cantero-Moreno D, Jimenes-OT C, Baenaruno S, Jimenez-Hornero J, Santos-Duenos I, Bonillavenceslada J, Barja F. "Estimating the mean acetification rate via on-line monitored changes in ethanol during a semi continuous vinegar production cycle". Journal of Food Engineering, 80(2), 460-464, 2006.

[9] Kayın N. Determination of Color Stability of Red Beet Juice Concentrate Stored at Different Temperatures. MSc Thesis, Abant Izzet Baysal University, Bolu, Turkey, 2014.

[10] Azeredo HMC. "Betalains: properties, sources, applications, and stability-a review". International Journal of Food Science \& Technology, 44, 2365-2376, 2008.

[11] Gandia-Herrero F, Escribano J, Garcia-Carmona F. "Structural implications on color, fluorescence, and antiradical activity in betalains". Planta, 232, 449-460, 2010.

[12] Jensen MB, Lopez-De-Dicastillo Bergamo CA, Payet RM, Liu X, Konczak I. "Influence of copigment derived from Tasmannia pepper leaf on Davidson's plum anthocyanins". Journal of Food Science, 76, 447-453, 2011.

[13] Strack D, Vogt T, Schliemann W. "Recent advances in betalain research". Phytochemistry, 62, 247-269, 2003.

[14] Kugler F, Graneis S, Schreiter PPY, Stintzing FC, Carle R. "Determination of free amino compounds in betalainic fruits and vegetables by gas chromatography with flame ionization and mass spectrometric detection". Journal of Agricultural and Food Chemistry, 54(12), 4311-4318, 2006.

[15] Hamouia R. The Color Changes and Antioxidant Properties of Beetroot (Beta Vulgaris L.) During Production. MSc Thesis, Ondokuz Mayıs University, Samsun, Turkey, 2018.

[16] Kapadia GJ, Azuine MA, Sridhar R, Okuda Y, Tsuruta A, Ichiishi E, Mukainake T, Takasaki M, Konoshima T, Nishino $\mathrm{H}$, Tokuda H. "Chemoprevention of DMBA-induced UV-B promoted, NOR-1-induced TPA promoted skin carcinogenesis, and DEN-induced phenobarbital promoted liver tumors in mice by extract of beetroot". Pharmacological Research, 47, 141-148, 2003.

[17] Winkler C, Wirleitner B, Schroecksnadel K, Schennach H, Fuchs D. "In vitro effects of beet root juice on stimulated and 110 Plant Foods Hum Nutr (2010) 65,105-111 unstimulated peripheral blood mononuclear cells". American Journal of Biochemistry and Biotechnology, 1, 180-185, 2005.

[18] Boo HO, Hwang SJ, Bae CS, Park SH, Heo BG, Gorinstein S. "Extraction and characterization of some natural plant pigments". Industrial Crops and Products, 40, 129-135, 2012.

[19] Rommel A, Heatherbell DA, Wrolstad RE. "Red raspberry juice and wine: effect of processing and storage on anthocyanin pigment composition, color and appearance". Journal of Food Science, 55(4), 1011-1017, 1990.

[20] AOAC. Association of Official Analytical Chemists, Official Methods of Analysis. 17th ed. AOAC, Washington DC, USA, 2000.

[21] Ünal E. A Study on Vinegar Production from Dimrit Grape by Different Methods. PhD Thesis, Cukurova University, Adana, Turkey, 2007. 
[22] Kırca A, Özkan M, Cemeroğlu B. "Effects of temperature, solid content and $\mathrm{pH}$ on the stability of black carrot anthocyanins". Food Chemistry, 101(1), 212-218, 2007.

[23] Alak GD. Some Physical, Chemical Properties of The Honey Vinegar and The Honey. MSc Thesis, Pamukkale University, Denizli, Turkey, 2015.

[24] Cemeroğlu B. Food Analysis. Ankara, Turkey, Food Technology Publications, 2007.

[25] Chu SC, Chen C. "Effects of origins and fermentation time on the antioxidant activities of Kombucha". Food Chemistry. 98, 502-507, 2006.

[26] Molyneux P. "The use of the stable free radical diphenylpicrylhydrazyl (DPPH) for estimating antioxidant activity". Songklanakarin Journal of Science and Technology, 26(2), 211-219, 2004.

[27] Fu L, Xie HL, Ferro MD. "Rapid multi-element analysis of Chinese vinegar by sector field inductively coupled plasma mass spectrometry". European Food Research and Technology, 237, 795-800, 2013.

[28] De Vero L, Gala E, Gullo M, Solieri L, Landi S, Giudici P. "Application of denaturing gradient gel electrophoresis (DGGE) analysis to evaluate acetic acid bacteria in traditional balsamic vinegar". Food Microbiology, 23, 809-813, 2006.

[29] Kneifel W, Berger E. "Microbiolgical criteria of random samples of spices and herbs retailed on the Austrian market". Journal of Food Protection, 57(10), 893-901, 1994.

[30] ISO. "21527-1:2008 Microbiology of food and animal feeding stuffs - Horizontal method for the enumeration of yeasts and moulds-Part 1: Colony count technique in products with water activity greater than $0.95 "$. Geneva, Switzerland, 2008.

[31] Altuğ Onoğur T, Elmacı Y. Sensory Evaluation in Foods. $2^{\text {nd }}$ ed. Izmir, Turkey, Sidas Publications, 2005.

[32] Budak NH. A Research on Compositional and Functional Properties of Vinegars Produced from Apple and Grape. PhD Thesis, Suleyman Demirel University, Isparta, Turkey, 2010.

[33] Er T. Effect of Different Drying Temperature on Some Physical and Phyto-Chemical Properties of Red Beet. MSc Thesis, Selcuk University, Konya, Turkey, 2011.

[34] Budak NH, Kumbul Doguc D, Savas CM, Seydim AC, Kok Tas T, Ciris MI, Guzel-Seydim ZB. "Effects of apple cider vinegars produced with different techniques on blood lipids in high-cholesterol-fed rats". Journal of Agricultural and Food Chemistry, 59(12), 6638-6644, 2011.
[35] Anonymous. "TS 1880 EN 13188 Vinegar Product Recipes, Features and Marking from Liquids of Agricultural Origin". Turkish Standards Institute, Ankara, Turkey, 2003.

[36] Aykın E. Determination of Bioactive Compounds in Mothers of Vinegar Produced from Different Vinegars. MSc Thesis, Suleyman Demirel University, Isparta, Turkey, 2013.

[37] Kadaş Z. Determination of Bioactive Properties and Metabolic Effects of Hawthorn Vinegar. MSc Thesis, Abant İzzet Baysal University, Bolu, Turkey, 2011.

[38] Marangoz IF. Effect on Bioactive Compounds and Antioxidant Properties of Mulberry Fruit of Vinegar Product Processing. MSc Thesis, Canakkale On Sekiz Mart University, Canakkale, Turkey, 2016.

[39] Plessi M. Vinegar. Editors: Caballero B, Finglas PM, Toldra F. Encyclopedia of Food Sciences and Nutrition, 5996-6004, Cambridge, ABD, Academic Press, 2003.

[40] Siddeeg A, Zeng XA, Rahaman A, Manzoor MF, Ahmed Z, Ammar AF. "Quality characteristics of the processed dates vinegar under influence of ultrasound and pulsed electric field treatments". Journal of Food Science and Technology, 56(9), 4380-4389, 2019.

[41] Kadas Z, Evrendilek GA, Heper G. "The metabolic effects of hawthorn vinegar in patients with high cardiovascular risk group". Journal of Food and Nutrition Research, 2(9), 539-545, 2014.

[42] Ozturk I, Caliskan O, Tornuk F, Ozcan N, Yalcin H, Baslar M, Sagdic 0. "Antioxidant, antimicrobial, mineral, volatile, physicochemical and microbiological characteristics of traditional home-made Turkish vinegars". LWT-Food Science and Technology, 63(1), 144-151, 2015.

[43] Kapukaya KS. Determination of Flame Atomic Absorption Spectroscopy of Metals of $\mathrm{Cu}, \mathrm{Cd}, \mathrm{Fe}, \mathrm{Mg}, \mathrm{Na}$ and $\mathrm{Zn}$ Found in Apple and Grape Vinegar Samples. MSc Thesis, Sütçü İmam Universtiy, Kahramanmaraş, Turkey, 2017.

[44] Şengün IYY, Kılıç G. "Microbiological, physical, chemical, antiradical and antimicrobial properties of mulberry vinegar". Academic Food Journal, 16(2), 168-175, 2018. 